\title{
The Effects of Perceived Justice and Emotions on Service Recovery Satisfaction on Indonesian B2B and C2C E-commerce Customers
}

\author{
Fatimah Azzahro \\ Faculty of Computer Science, \\ Universitas Indonesia \\ Kampus UI Depok, Depok, \\ West Java, 16424, Indonesia \\ azzahro.fatimah@cs.ui.ac.id
Faculty of Computer Science, Universitas Indonesia
Kampus UI Depok, Depok,
West Java, 16424, Indonesia
putu.wuri@cs.ui.ac.id \\ Putu Wuri Handayani
}

\author{
Sandya Sekar Murti \\ Faculty of Computer Science, \\ Universitas Indonesia \\ Kampus UI Depok, Depok, \\ West Java, 16424, Indonesia \\ sandyasekarmurti@gmail.com \\ Satrio Baskoro Yudhoatmojo \\ Department of Systems Science and \\ Industrial Engineering, \\ Binghamton University, New York, 13850, \\ United States \\ syudhoa1@binghamton.edu
}

\begin{abstract}
This study aims to analyze the effects of justice theory and emotions on service recovery satisfaction of Indonesian e-commerce customers. The factors used in this study are distributive justice, procedural justice, interactional justice, as cognitive aspect. Positive emotions and negative emotions are the factors used as affective aspect. This study used quantitative approach in the form of online survey. The total amount of data used in this study are 601 data. The respondents are Indonesian B2C or C2C e-commerce customer who

filed a complaint directly to the $B 2 \mathrm{C}$ or $C 2 \mathrm{C}$ e-commerce at least once and receives a response at least once. Covariance-based structural equation modelling is used to analyze the data. The analysis results show that distributive justice, procedural justice, interactional justice, and positive emotions affect service recovery satisfaction. The results of this study

can help Indonesian $B 2 C \& C 2 C$ e-commerce to understand service recovery from the perspective of customers, so satisfactory service recovery can be implemented.
\end{abstract}

Keywords: Service recovery, service recovery satisfaction, B2C e-commerce, C2C ecommerce, complaint handling, service failure

\section{Introduction}

Based on data collected by Statista in 2016, Indonesia ranks first among ASEAN countries with sales of retail products through e-commerce of $\$ 5.29$ billion US dollars. The competition between ecommerce is fierce. Customers spoiled by various attractive offers made by e-commerce platforms. According to Katadata, Tokopedia became the leader of Indonesia's e-commerce industry with 153.6 million visitors per month, followed by Bukalapak (95.9 million) and Shopee (38.9 million) (Katadata, 2018). Due to the fierce competition between e-commerce platforms, getting new customers and maintaining existing customers become a more difficult task (Swaid \& Wigand (2009) in Liao et al., (2017). It becomes even worse due to customers' low loyalty to e-commerce platforms (Liao et al., 
2017). Thus, in order to survive, e-commerce platforms should pay attention to factors that may improve customers' loyalty.

According to Priambada (2016), there are three main expectations of customers for the improvement of e-commerce in Indonesia, namely an increase in promos / discounts, an increase in product quality, and an increase in customer service responsiveness. This finding is also supported by research conducted by DailySocial in 2016 which found that responsive customer service is one of the determining factors for customer satisfaction (Priambada, 2016). However, 40.67\% of respondents are still experience problems when using e-commerce services (Priambada, 2016). Based on YLKI data in 2017, most of complaints are made due to the slow response in handling customers' complaints (44\%), slow products delivery (36\%), and problematic refunds (17\%) (Bayu, 2018). When dealing with problems, good service recovery can build dedication and trust between customers and e-commerce platforms, which increases customer satisfaction and loyalty (Ozuem et al., 2017). This finding is also supported by Harris et al. (2006) and Maxham (2001) that found that effective service recovery strategies can increase customer satisfaction, repurchase intention, positive word-of-mouth, and stronger corporate image (Yeoh et al., 2014). Conversely, failure to correct customer problems can cause customers to move to competitors, or worse, spread negative word-of-mouth that harms the service provider (Yeoh et al., 2014; Ozuem et al., 2017).

Several studies have been conducted to determine the factors that influence service recovery satisfaction by using justice theory as a cognitive and emotional aspect as an affective aspect, namely in the aviation industry conducted by Wen and Chi (2013) and Nikbin and Hyun (2015), on B2C e-commerce conducted by Urueña and Hidalgo (2016), and at higher education institutions conducted by Waqas, Ali and Khan (2014). Wen and Chi (2013) argues that justice theory has become a strong theory to be the basis of service recovery satisfaction research.

Of the five studies, there is no research that aims to determine the effect of justice theory and emotions on e-commerce customers in Indonesia. In addition, most of the previous studies still focused on service recovery satisfaction in the offline context. Research conducted by Urueña and Hidalgo (2016) on B2C e-commerce also has not tested each dimension of justice theory to other factors such as positive emotions and negative emotions. In addition, it was also found that there have been no previous studies related to service recovery satisfaction in $\mathrm{B} 2 \mathrm{C} \& \mathrm{C} 2 \mathrm{C}$ e-commerce customers as well. Thus, this research tries to fill the research gap by to conduct research on service recovery satisfaction in Indonesian e-commerce customers, especially $\mathrm{B} 2 \mathrm{C}$ as well as $\mathrm{C} 2 \mathrm{C}$ e-commerce because e-commerce with this business model in Indonesia is very popular.

\section{Literature Review}

\section{Service Failure}

Even the best companies have difficulty avoiding mistakes while serving customers (Wen and Chi, 2013). This error is also called a service failure. According to Smith, Bolton, \& Wagner (1999) in Wong, Newton and Newton (2016), service failure occurs when the service received by a customer does not match customer expectations. Pizzutti and Fernandes (2010) classifies service failures in e-commerce into two categories, namely process failure and outcome failure. Process failure consists of late delivery, information that is incompatible with the product received (bad information), problems with the system / website, and problems with customer service (Pizzutti and Fernandes, 2010). Whereas, outcome failure consists of incorrect billing, incorrect products, defective products, and products have never been received (Pizzutti and Fernandes, 2010). This is supported by Urueña and Hidalgo (2016) that found that the three main reasons for $\mathrm{B} 2 \mathrm{C}$ e-commerce customers to file complaints are shipping problems, damaged / defective products, and receiving the wrong product. 


\section{Service Recovery Satisfaction}

To correct service failures experienced by customers, companies usually perform service recovery procedures. Neira \& Casielles (2010) in Waqas, Ali and Khan (2014) said that service recovery is a series of activities carried out to repair and compensate customers for service failures that aims to maintain companies' credibility and recover customers' satisfaction (Danaher \& Mattsson, 1994; Grönroos, 1990; Sparks \& McColl-Kennedy, 2001 in Ding and Lii, 2016). Service recovery is often performed in forms of sending apologies and explanations, offering solutions, compensation, or other actions to quickly resolve problems while maintaining a polite and respectful attitude towards customers who submit complaints (Mostafa et al., 2015). Companies should be cautious during service recovery process. Failed to perform a successful service recovery process can harm companies in various ways.

According to Orsingher, Valentini and de Angelis (2010), satisfaction with complaint handling is the customer's evaluation of how well a company handles problems. Meanwhile, according to Huang (2011), service recovery satisfaction is a positive assessment from customers when comparing profits and sacrifices obtained from service failure with consequences obtained from problems (MolinerVelázquez, Ruiz-Molina and Fayos-Gardó, 2015). Therefore, it can be concluded that service recovery satisfaction is customer satisfaction with the process and results they obtained from the service recovery provided by the company, when compared with initial expectations and sacrifices made by the customer.

\section{Interactional, Procedural, and Distributive Justice}

In handling problems faced by customers, companies must also pay attention to aspects of justice to customers. According to Río-Lanza et al., Adam's theory of perceived justice is an appropriate tool for studying individual reactions when performing complaint behavior (del Río-Lanza, Vázquez-Casielles and Díaz-Martín, 2009). In the theory of perceived justice, Adam introduced three dimensions of justice namely interactional justice, procedural justice, and distributive justice.

Distributive justice is defined as a customer's evaluation of the results obtained from filing complaints, and whether the results make sense or not (Waqas, Ali and Khan, 2014). Meanwhile, Wen and Chi (2013) defines distributive justice as the customer's response to what he gets from service recovery. Of course, customers hope that the company can compensate the losses suffered by customers (Wen \& Chi, 2013). In addition, customers also expect something 'more' during service recovery, such as an apology, refund, or repair (Wen \& Chi, 2013). Then, it can be concluded that distributive justice is the customer's assessment of the output obtained for complaints that he submits, both material (compensation, refunds, etc.) or immaterial (apologies) when compared with the problems experienced and their impact.

Meanwhile, interactional justice is defined by Wen \& Chi (2013) as a customer assessment of how service providers and their employees treat customers. Urueña \& Hidalgo (2016) defines interactional justice as justice that is received by customers in interactions with company employees during the service recovery process. Customers expect employees to be respectful, caring, honest, and willing to help solve the problems they face (Wen \& Chi, 2013). Therefore, in this study, interactional justice is defined as a customer assessment of customer service attitudes in serving customers, which includes sincerity, courtesy, honesty, and empathy.

The last dimension, namely procedural justice, is defined by Wen \& Chi (2013) as the customer's opinion on the service recovery process provided, where the company can be held accountable for its mistakes, handle complaints immediately, and resolve problems experienced quickly. Therefore, procedural justice focuses on aspects of accessibility, speed, and flexibility in handling the problems experienced by customers (Nikbin and Hyun, 2015). 


\section{Conceptual Model and Hypotheses}

\section{Distributive justice and its influence on positive emotion, negative emotion, and service satisfaction recovery}

When experiencing service failure, customers certainly expect the company to be able to compensate for the losses they experience (Wen \& Chi, 2013). In the theory of distributive justice, customers often expect a solution to the problem that is at least equivalent to the effort and impact caused by the problem. Often, customers also expect something 'more' during service recovery, such as an apology, refund, or repair (Wen \& Chi, 2013). The solution of this problem must also offer a fair and profitable solution (Maxham and Netemeyer, 2002), appropriate (Kim \& Smith, 2005), and show the efforts of service providers to solve the problem. Customers also want to solve problems that are accompanied by clear reasons (Colquitt, 2001).

Solving problems both materially and immaterially can certainly affect customer emotions, as has been proven in several previous studies. Research conducted by Kim \& Tang (2016) on service recovery in restaurants proves that distributive justice is the factor that most influences the emotions felt by customers. This may happen because distributive justice is the most easily assessed and most obvious dimension (Kim and Tang, 2016). Kuo and $\mathrm{Wu}$ (2012) found that the ability of service providers to provide distributive justice for example in the form of discounts and refunds can make customers feel happy and satisfied. Conversely, if the company cannot provide fair and appropriate handling of problems, customers can feel negative emotions such as anger and resentment.

In addition, Wen \& Chi (2013) said that providing fair solutions can improve customer satisfaction, while the company's failure to provide fair compensation can result in reduced customer satisfaction. Yeoh et al. (2015) who conducted research related to service recovery satisfaction in online shopping found that the most effective strategy to improve service recovery satisfaction was to provide replacement or refund after direct service failure. With the solution to the problem of providing compensation or other solutions that are in accordance with the impact of the problem faced by the customer, this can restore customer satisfaction. Therefore, we proposed the following hypothesis.

H1: Distributive justice positively influences positive emotions

H2: Distributive justice negatively affects negative emotions

H3: Distributive justice positively affects service recovery satisfaction

\section{Interactional justice and its influence on positive emotion, negative emotion, and service satisfaction recovery}

Interactional justice is defined by Urueña \& Hidalgo (2016) as the equality that is received by customers when interacts with companies' employees during the service recovery process. Customers expect employees to be respectful, caring, honest, and willing to help solve the problems they face (Wen \& Chi, 2013). Therefore, in this study, interactional justice is defined as a customer assessment of customer service attitudes in solving customer problems, which include sincerity, courtesy, honesty, empathy, and efforts to solve problems.

Customers who are treated unfairly by employees during service recovery may feel angry and disappointed (Wen \& Chi, 2013). This is also supported by the findings of Mccoll-Kennedy and Sparks (2003) which states that employees who do not serve customers well, especially when facing problems, can cause negative emotions to customers. Conversely, employees who are polite and empathetic will encourage positive emotions in customers (Wen \& Chi, 2013). Therefore, social interaction between companies' employees and customers is crucial in determining customer emotions, especially when customers experience service failures.

Waqas, Ali, \& Khan (2014) argue that during service failures, customer satisfaction can still be achieved by offering emphatic, sincere and polite behavior while trying to resolve the issues. This is also supported by Yeoh et al. (2015) who found that customer satisfaction would increase if the interaction between customers and online retailers are fill with empathy and friendliness. Thus, during the service 
recovery process, online retailers need to submit apologies, respect customers, and provide an appropriate explanation for the service failure (Yeoh et al., 2015). The majority of Indonesian people are friendly, so cold interactions and lack of empathy can reduce customer satisfaction with the service recovery process (Refiana, 2012). Therefore, the authors draw the following hypothesis:

H4: Interactional justice positively influences positive emotions

H5: Interactional justice negatively affects negative emotions

H6: Interactional justice positively affects service recovery satisfaction

\section{Procedural justice and its influence on positive emotion, negative emotion, and service satisfaction recovery}

The final dimension of justice theory, namely procedural justice, is defined by Wen \& Chi (2013) as the customer's opinion on the service recovery process provided, where the company can be held accountable for its mistakes, handle complaints promptly, and resolve problems quickly. Therefore, procedural justice focuses on procedures for handling problems that have good accessibility, speed, and flexibility in handling problems experienced by customers (Nikbin \& Hyun, 2014).

The ability of companies to solve problems quickly with flexible procedures can produce positive emotions in customers and reduce negative emotions such as anger and frustration (Wen \& Chi, 2013). This is also supported by research by Nikbin \& Hyun (2014) who found that customers feel fewer negative emotions when customers are treated with fair procedures. In addition, procedural justice can also affect the service recovery satisfaction felt by customers (Waqas, Ali, \& Khan, 2014). Therefore, the authors proposed hypotheses as follows:

H7: Procedural justice positively influences positive emotions

H8: Procedural justice negatively affects negative emotions

H9: Procedural justice positively affects service recovery satisfaction

\section{Positive emotion and negative emotion as the antecedents of service satisfaction recovery}

The results of research conducted by Urueña \& Hidalgo (2016) show that positive emotions and negative emotions can affect service recovery satisfaction. Therefore, it is important for companies to train employees to be able to manage customer emotions, especially positive emotions when customers submit complaints. Many customers feel strong emotions when experiencing service failure and during the service recovery process (Wen \& Chi, 2013). If these emotions are not controlled, this can lead to customer dissatisfaction (Wen \& Chi, 2013). Thus, companies must pay attention to customer emotions that are seen from the tone of speech and phrases (Kuo \& Wu, 2012).

In addition, companies must be able to increase customer positive emotions and manage their negative emotions to be able to increase satisfaction (Kuo \& Wu, 2012). If the service recovery provided can make customers feel positive emotions such as feeling calm and happy, then the customer can return to the condition of satisfaction despite experiencing service failure. Conversely, if the service recovery provided makes the customer feel negative emotions such as frustration, anger, and disappointment, then this indicates that the recovery service provided does not satisfy the customer. Therefore, the authors formulated the following hypotheses.

H10: Positive emotions affect service recovery satisfaction positively

H11: Negative emotions negatively affect service recovery satisfaction 


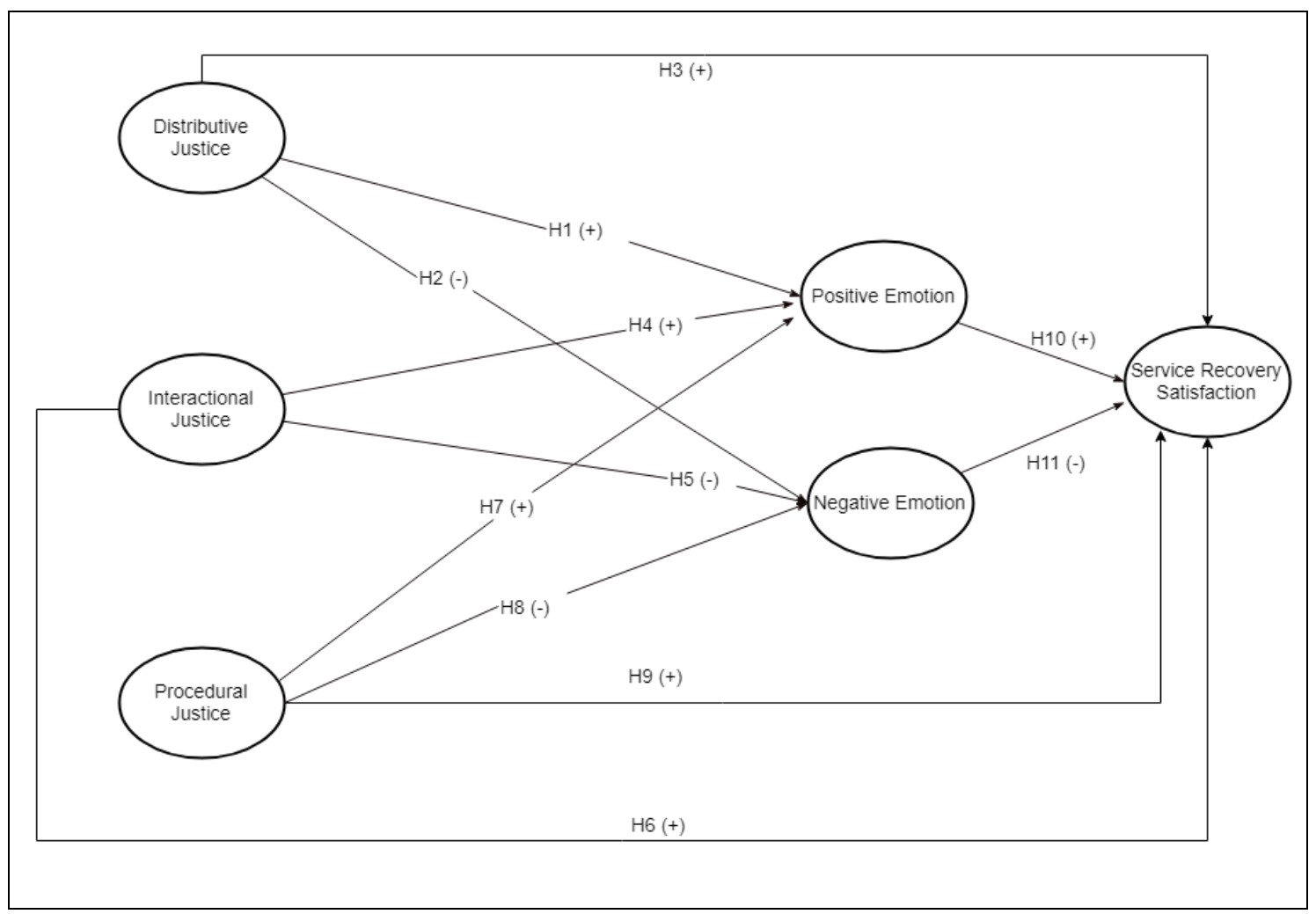

Figure 1. The Proposed Research Model

\section{Research Methodology}

\section{Sampling and data collection}

The authors conduct the readability test to ensure that the questionnaire can be answered by respondents. 11 respondents from the various background are asked to comment on the initial questionnaire. After completing the readability test, the questionnaire is distributed using an online questionnaire that can be accessed via the link bit.ly/komplainecom2. The author uses social media such as Twitter, Facebook, Instagram, Line, and LinkedIn to facilitate the questionnaires distribution. The data collection technique used by the author is purposive sampling, which is the technique of selecting respondents according to predetermined criteria. The criteria that determine the author in choosing a research sample are $\mathrm{B} 2 \mathrm{C}$ or $\mathrm{C} 2 \mathrm{C}$ Indonesian e-commerce users (either as sellers or buyers) who have asked for complaints to customer service at least once and received a response at least once from the e-commerce customer service.

\section{Demographics of Respondent}

The amount of valid data to be analyzed is 601 data. According to Kline (2016), the number of respondents should be grated that 10 times the research indicators. Since this study uses 26 indicators, the amount of collected data is sufficient to be further analyzed. Table 1 summarizes the demographic characteristics of the respondents. 
Table 1. Respondent Demographics

\begin{tabular}{|c|c|c|}
\hline \multirow{2}{*}{ Gender } & Men & $28.62 \%$ \\
\hline & Women & $71.38 \%$ \\
\hline \multirow{4}{*}{ Age } & $<=20$ years & $16.81 \%$ \\
\hline & $21-30$ years & $72.88 \%$ \\
\hline & $31-40$ years & $9.82 \%$ \\
\hline & $>40$ years & $0.50 \%$ \\
\hline \multirow{5}{*}{ Education Level } & High School & $27.45 \%$ \\
\hline & Diploma & $9.82 \%$ \\
\hline & Bachelor & $59.07 \%$ \\
\hline & Master & $3.33 \%$ \\
\hline & Others & $0.33 \%$ \\
\hline \multirow{5}{*}{$\begin{array}{l}\text { Monthly income / } \\
\text { Allowance (in } \\
\text { Thousand Indonesia } \\
\text { Rupiah) }\end{array}$} & $<$ IDR 500 & $12.81 \%$ \\
\hline & IDR $500-1000$ & $10.65 \%$ \\
\hline & IDR $1001-5000$ & $50.25 \%$ \\
\hline & IDR $5001-10000$ & $22.63 \%$ \\
\hline & $>$ IDR 10000 & $3.66 \%$ \\
\hline \multirow{4}{*}{$\begin{array}{l}\text { Problems in E- } \\
\text { commerce }\end{array}$} & $\begin{array}{l}\text { Problems with the } \\
\text { systems }\end{array}$ & $30.62 \%$ \\
\hline & $\begin{array}{l}\text { Product does not } \\
\text { match the } \\
\text { description }\end{array}$ & $25.29 \%$ \\
\hline & Delivery problem & $35.61 \%$ \\
\hline & Other Problems & $8.49 \%$ \\
\hline \multirow{6}{*}{$\begin{array}{l}\text { Length of time for } \\
\text { resolving the } \\
\text { problems }\end{array}$} & Less than a day & $21.30 \%$ \\
\hline & $1-3$ days & $49.08 \%$ \\
\hline & 4-6 days & $8.99 \%$ \\
\hline & $1-2$ weeks & $10.32 \%$ \\
\hline & $>2$ weeks & $3.16 \%$ \\
\hline & Never resolved & $7.15 \%$ \\
\hline
\end{tabular}

\section{Research Results}

\section{Measurement Model Evaluation}

In order to evaluate the measurement model, we use three type of test that consist of convergent validity, reliability, and discriminant validity tests. In validity testing, we must ensure that the loading factor for each indicator is more than 0.70. Meanwhile, the AVE value must be greater than 0.5 (Santoso, 2015). If the indicator has a loading factor less than 0.7 , then the loading factor can be eliminated or set the error variance to 0.01 (Wijanto, 2015). Next, we check whether the value of CR and CA are greater than the cut-off value of 0.7. In addition, the AVE value of each factor must be greater than 0.5 . The calculation results show that the CR, CA, and AVE values pass all the cut off value (see Table 2). 
Table 2. The Results of CR, CA, AVE and Square Root of AVE

\begin{tabular}{|l|l|l|l|l|l|l|l|l|l|}
\hline Factors & SRS & DJ & EN & EP & PJ & IJ & CR & CA & AVE \\
\hline SRS & $\mathbf{0 . 8 8 2}$ & & & & & & 0.873 & 0.866 & 0.777 \\
\hline DJ & 0.692 & $\mathbf{0 . 8 6 9}$ & & & & & 0.858 & 0.830 & 0.756 \\
\hline EN & -0.339 & -0.347 & $\mathbf{0 . 9 0 4}$ & & & & 0.957 & 0.932 & 0.817 \\
\hline EP & 0.785 & 0.739 & -0.398 & $\mathbf{0 . 9 1 1}$ & & & 0.936 & 0.964 & 0.829 \\
\hline PJ & 0.668 & 0.605 & -0.343 & 0.707 & $\mathbf{0 . 8 7 2}$ & & 0.861 & 0.880 & 0.760 \\
\hline IJ & 0.772 & 0.745 & -0.435 & 0.838 & 0.725 & $\mathbf{0 . 8 7 7}$ & 0.952 & 0.936 & 0.769 \\
\hline
\end{tabular}

Next, to evaluate the measurement model, we must check the goodness of fit by evaluating the value of CMIN / df, RMSEA, NFI, CFI, GFI, TLI, and RMR. Each of these criteria must pass the predetermined cut-off value to be considered as a fit model. The result of goodness of fit measurement model can be seen in Table 3.

Table 3. The Result of Goodness of Fit Measurement Model

\begin{tabular}{|c|l|l|l|}
\hline Criteria & \multicolumn{1}{|c|}{ Cut-off value } & \multicolumn{1}{|c|}{ Results } & \multicolumn{1}{|c|}{ Remarks } \\
\hline CMIN/df & $<2.0$ & 1.998 & Good fit \\
\hline GFI & $\geq 0.9$ & 0.947 & Good fit \\
\hline NFI & $\geq 0.9$ & 0.975 & Good fit \\
\hline CFI & $\geq 0.9$ & 0.987 & Good fit \\
\hline RMR & $\leq 0.05$ & 0.04 & Good fit \\
\hline TLI & $\geq 0.9$ & 0.983 & Good fit \\
\hline RMSEA & $\leq 0.08$ & 0.045 & Good fit \\
\hline
\end{tabular}

\section{Structural Model Evaluation}

After evaluating measurement model, we evaluate the structural model by calculating the R-square value and performing hypothesis testing. $\mathrm{R}$ squared value represents the proportion of the variance of a factor explained by the predictor of that factor (Bryne, 2010). Thus, by looking at the R squared value, it can show how far a factor can be explained by their exogen factors. The value of $\mathrm{R}$ squared of this model can be seen in Table 4 .

The negative emotions factor can be explained by its predictors factor, namely distributive justice, procedural justice, and interactional justice by $17.6 \%$. Meanwhile, the positive emotions factor can be explained by its predictors namely distributive justice, procedural justice, and interactional justice by 75.4\%. Lastly, the service recovery satisfaction factor can be explained by its predictors namely distributive justice, procedural justice, interactional justice, positive emotions, and negative emotions by $67.1 \%$.

Table 4. R Squared Value

\begin{tabular}{|c|l|}
\hline Factor & $\mathbf{R}^{2}$ Value \\
\hline EN & 0.176 \\
\hline EP & 0.754 \\
\hline SRS & 0.671 \\
\hline
\end{tabular}


Next, we perform one tail hypothesis testing to evaluate the proposed hypothesis. A hypothesis will be accepted if its $\mathrm{p} / 2<0.05$. The result of hypothesis can be seen in Table 5. Among 11 hypotheses, 3 hypotheses are rejected while the rest are accepted.

Table 5. Hypothesis Testing

\begin{tabular}{|l|l|l|l|l|l|}
\hline \multicolumn{4}{|c|}{ Hypotheses } & P-Value & \multicolumn{1}{|c|}{ Result } \\
\hline H1 & EP & $\leftarrow$ & DJ & 0.002 & Accepted \\
\hline H2 & EN & $\leftarrow$ & DJ & 0.49 & Rejected \\
\hline H3 & SRS & $\leftarrow$ & DJ & 0.003 & Accepted \\
\hline H4 & EP & $\leftarrow$ & PJ & 0.004 & Accepted \\
\hline H5 & EN & $\leftarrow$ & PJ & 0.594 & Rejected \\
\hline H6 & SRS & $\leftarrow$ & PJ & 0.019 & Accepted \\
\hline H7 & EP & $\leftarrow$ & IJ & 0.002 & Accepted \\
\hline H8 & EN & $\leftarrow$ & IJ & 0.004 & Accepted \\
\hline H9 & SRS & $\leftarrow$ & IJ & 0.002 & Accepted \\
\hline H10 & SRS & $\leftarrow$ & EP & 0.004 & Accepted \\
\hline H11 & SRS & $\leftarrow$ & EN & 0.828 & Rejected \\
\hline
\end{tabular}

\section{Discussion}

Based on Table 5, distributive justice is proven to positively influence positive emotions. This result is in accordance with research conducted by Kuo \& Wu (2012) who examined service recovery satisfaction in online shopping, which said that the ability of service providers to provide distributive justice for example in the form of discounts, refunds, and improving the quality of goods to avoid customers issuing more a lot of costs, will make customers feel positive emotions. Meanwhile, distributive justice is not proven to have a negative influence on negative emotions. These results are consistent with the study of Wen \& Chi (2013), which states that customers who experience flight delays do not expect compensation from the airline. Thus, the absence of compensation does not always cause negative emotions to customers (Wen \& Chi, 2013). Additionally, we found that there is a positive correlation between distributive justice and service recovery satisfaction. These results are consistent with the study of Wen \& Chi (2013) which says that providing fair solutions to compensate for customer losses can increase customer satisfaction with service recovery.

Furthermore, this study shows that there is a positive relationship between procedural justice and positive emotions, where good procedures will increase customers' positive emotions, while procedures that are less good will reduce customer positive emotions. This result is in line with the study of Wen \& Chi (2013) which says that solving problems as quickly as possible and flexible procedures can produce positive emotions on customers such as feeling happy and happy. Additionally, there is a positive relationship between interactional justice and negative emotions in Indonesian $\mathrm{B} 2 \mathrm{C} \& \mathrm{C} 2 \mathrm{C}$ ecommerce customers. These results are consistent with previous studies conducted by Wen \& Chi (2013), Urueña \& Hidalgo (2016), and Nikbin \& Hyun (2014). Customers who are treated unfairly will cause negative emotions to customers, such as anger and disappointment (Wen \& Chi, 2013). Social interaction with customers is very important in determining customer emotions (Nikbin \& Hyun, 2014).

Lastly, this research show that the stronger positive emotions felt by customers, customer satisfaction will increase. Conversely, if positive customer emotions are reduced, then customer satisfaction will also be reduced. These results are in line with research conducted by Urueña \& Hidalgo (2016) and Kuo $\& \mathrm{Wu}$ (2012). According to Kuo \& Wu (2012), encouraging positive emotions in customers who submit complaints can increase customer satisfaction. 


\section{Conclusion}

This study aims to analyze the effect of justice theory and emotions on service recovery satisfaction on Indonesian e-commerce customers. To collect research data, the authors distribute online questionnaires and then evaluate the collected data by using CB SEM approach. Based on the results, it can be concluded that the negative emotions factor is not proven to affect the service recovery satisfaction of Indonesian B2C \& C2C e-commerce customers. Meanwhile, distributive justice and procedural justice factors were not proven to affect negative emotions felt by customers because of service recovery performed by B2C \& C2C e-commerce in Indonesia. Factors that have been proven to influence positive emotions are the three dimensions of justice, namely procedural justice, distributive justice, and interactional justice. Additionally, interactional justice is the only factor that have been proven to have influence on negative emotions. Lastly, distributive justice, procedural justice, interactional justice, and positive emotions influence service recovery satisfaction. Thus, it can be concluded that the three dimensions of justice are important factors that affect service recovery satisfaction, while the affective aspects that need to be considered to increase customer satisfaction are positive emotions.

\section{References}

Bayu, J. D. (2018) YLKI: Keluhan Terbanyak Konsumen Selama 2017 Soal Toko Online. Available at: https://katadata.co.id/berita/2018/01/19/ylki-keluhan-terbanyak-konsumen-\%09selama-2017soal-toko-online.

Bryne, B. (2010) Structural Equation Modeling with AMOS: Basic Concepts, Applications, and Programming, Structural Equation Modeling.

Ding, M. C. and Lii, Y. S. (2016) 'Handling online service recovery: Effects of perceived justice on online games', Telematics and Informatics, 33(4), pp. 881-895. doi: 10.1016/j.tele.2016.02.001.

Katadata (2018) Lazada, e-Commerce Paling Banyak Pengunjung TW I 2018 - Databoks. Available at: https://databoks.katadata.co.id/datapublish/2018/04/18/lazada-e-commerce-paling-banyakpengunjung-tw-i-2018.

Kim, E. and Tang, R. (Liang) (2016) 'Rectifying Failure of Service: How Customer Perceptions of Justice Affect Their Emotional Response and Social Media Testimonial', Journal of Hospitality Marketing and Management, 25(8), pp. 897-924. doi: 10.1080/19368623.2016.1149537.

Kline, R. B. (2016) Principles and practices of structural equation modelling (Fourth Edition), Methodology in the social sciences.

Kuo, Y. F. and Wu, C. M. (2012) 'Satisfaction and post-purchase intentions with service recovery of online shopping websites: Perspectives on perceived justice and emotions', International Journal of Information Management, 32(2), pp. 127-138. doi: 10.1016/j.ijinfomgt.2011.09.001.

Liao, C. et al. (2017) 'Factors influencing online shoppers' repurchase intentions: The roles of satisfaction and regret', Information and Management, 54(5), pp. 651-668. doi: 10.1016/j.im.2016.12.005.

Maxham, J. G. and Netemeyer, R. G. (2002) 'Modeling customer perceptions of complaint handling over time: The effects of perceived justice on satisfaction and intent', Journal of Retailing, 78(4), pp. 239-252. doi: 10.1016/S0022-4359(02)00100-8.

Mccoll-Kennedy, J. R. and Sparks, B. A. (2003) 'Application of Fairness Theory to Service Failures and Service Recovery', Journal of Service Research, 5(3), pp. 251-266. doi: $10.1177 / 1094670502238918$.

Moliner-Velázquez, B., Ruiz-Molina, M. E. and Fayos-Gardó, T. (2015) 'Satisfaction with service recovery: moderating effect of age in word-of-mouth', Journal of Consumer Marketing, 32(6), pp. 470-484. doi: 10.1108/JCM-12-2014-1251.

Mostafa, R. B. et al. (2015) 'Corporate Image: A Service Recovery Perspective', Journal of Service Research, 18(4), pp. 468-483. doi: 10.1177/1094670515584146.

Nikbin, D. and Hyun, S. S. (2015) 'An empirical study of the role of failure severity in service recovery evaluation in the context of the airline industry', Review of Managerial Science, 9(4), pp. 731749. doi: 10.1007/s11846-014-0135-7.

Orsingher, C., Valentini, S. and de Angelis, M. (2010) 'A meta-analysis of satisfaction with complaint handling in services', Journal of the Academy of Marketing Science, 38(2), pp. 169-186. doi: 
10.1007/s11747-009-0155-z.

Ozuem, W. et al. (2017) 'An exploration of consumers' response to online service recovery initiatives', International Journal of Market Research, 59(1), pp. 97-116. doi: 10.2501/IJMR-2016-048.

Pizzutti, C. and Fernandes, D. (2010) 'Effect of recovery efforts on consumer trust and loyalty in e-tail: A contingency model', International Journal of Electronic Commerce, 14(4), pp. 127-160. doi: 10.2753/JEC1086-4415140405.

Priambada, A. (2016) Customer Satisfaction in Indonesia's E-Commerce Services, Dailysocial. Available at: https://dailysocial.id/report/post/customer-satisfaction-in-indonesias-e-commerceservices.

Refiana, L. (2012) 'Qualitative Analysis about Consumer Complaint Response through Reader's Letter Column in Kompas.com', Procedia - Social and Behavioral Sciences, 65, pp. 83-87. doi: 10.1016/j.sbspro.2012.11.095.

del Río-Lanza, A. B., Vázquez-Casielles, R. and Díaz-Martín, A. M. (2009) 'Satisfaction with service recovery: Perceived justice and emotional responses', Journal of Business Research, 62(8), pp. 775-781. doi: 10.1016/j.jbusres.2008.09.015.

Santoso, S. (2015) AMOS 22 untuk structural equation modelling. Jakarta: Elex Media Komputindo.

Urueña, A. and Hidalgo, A. (2016) 'Successful loyalty in e-complaints: FsQCA and structural equation modeling analyses', Journal of Business Research, 69(4), pp. 1384-1389. doi: 10.1016/j.jbusres.2015.10.112.

Waqas, M., Ali, H. and Khan, M. A. (2014) 'An investigation of effects of justice recovery dimensions on students' satisfaction with service recovery in higher education environment', International Review on Public and Nonprofit Marketing, 11(3), pp. 263-284. doi: 10.1007/s12208-014-01205.

Wen, B. and Chi, C. G. (2013) 'Examine the cognitive and affective antecedents to service recovery satisfaction', International Journal of Contemporary Hospitality Management, 25(3), pp. 306327. doi: 10.1108/09596111311310991.

Wijanto, S. (2015) Metode Penelitian Menggunakan Structural Equation Modeling dengan LISREL 9. Jakarta: Lembaga Penerbit Fakultas Ekonomi UI.

Wong, J., Newton, J. D. and Newton, F. J. (2016) 'Powerlessness following service failure and its implications for service recovery', Marketing Letters, 27(1), pp. 63-75. doi: 10.1007/s11002-0149303-4.

Yeoh, P.-L. et al. (2014) 'Customer Response to Service Recovery in Online Shopping', Journal of Services Research, 14(2), pp. 33-56. 